\author{
N.Yu. Selikhova, V.S. Malkov, A.A. Bakibaev \\ National Research Tomsk State University, Tomsk, Russia \\ (E-mail: selikhova.n@mail.ru)
}

\title{
Reaction between guaiacol and glyoxalic acid under microwave irradiation
}

\begin{abstract}
In this paper, we considered the opportunity to use microwave irradiation as an alternative to the convection heating method during the guaiacol condensation reaction with glyoxalic acid in an aqueous solution in the presence of sodium hydroxide in order to preparatively obtain the 4-hydroxy-3-methoxymindic acid, an intermediate of the vanillin synthesis. The experiments under the influence of the microwave irradiation were carried out using the «Speedwave four» microwave system that allowed varying the irradiation power in the range from 0 to $1450 \mathrm{~W}$. The condensation reaction was carried out at the irradiation power of 290, 580, 870, and $1160 \mathrm{~W}$. The effects of time, temperature and microwave radiation power on the desired product yield of the condensation reaction was established by varying the reaction conditions during the experiments. Using this method, the experimental conditions of highest product yield were determined when temperature of the reaction mixture, the irradiation power and synthesis time were $70{ }^{\circ} \mathrm{C}, 870 \mathrm{~W}$, and 30 minutes respectively. A comparison of the results of the synthesis of 4-hydroxy-3-methoxymindic acid under the microwave activation and for the conventional procedure was performed. The use of the microwave irradiation was found to significantly reduce (up to 20 times) the synthesis time, however, the maximum product yield achieved by this method turned out to be lower compared to the one obtained by conventional procedure. The 4-hydroxy-3-methoxymindic acid synthesized samples structure was confirmed using IR, 1H and 13C NMR spectroscopy.
\end{abstract}

Keywords: vanillylmandelic acid, guaiacol, glyoxalic acid, condensation, microwave irradiation.

\section{Introduction}

4-Hydroxy-3-methoxymindic acid (2) (vanillylmandelic acid, VMA) is an important intermediate in the vanillin synthesis (3) using the guaiacol method [1-4] (Fig. 1). This method is more ecofriendly than the one used to produce vanillin from the lignin-containing raw materials and allows obtaining the desired product (2) of high quality with lower cost as compared with the natural vanillin and the one obtained from the natural raw materials.

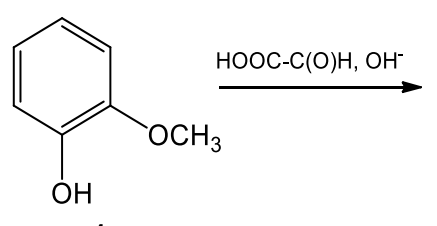

1

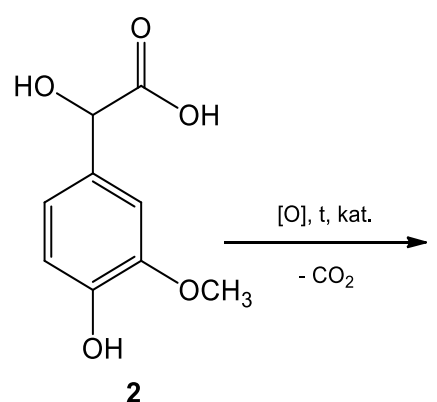

2

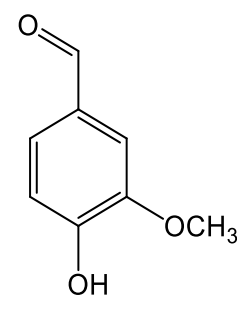

3

Figure 1. Vanillin synthesis using guaiacol method

It is noteworthy that the key disadvantage of the abovementioned method of vanillin preparation is the significant duration of the guaiacolate condensation with glyoxylate that can exceed a day [2].

The condensation time can be reduced by increasing the temperature, however, the prolonged heating of the reaction mixture in the case of guaiacol and glyoxalic acid decreases the yield of the desired product due to the acceleration of the side reactions [5] as well as due to the instability of glyoxalic acid upon heating [2]. The use of the special catalysts [6-8] can also reduce the duration of the condensation stage, but this approach significantly increases the costs of vanillin production (3).

One of the methods to increase the rate of many organic reactions is to use the microwave radiation. The advantages of this approach include the uniformity and the absence of delayed heating of the reaction mixture, the opportunity for rapid temperature control and the instant energy supply cut as well as a number of other 
parameters [9]. Although the mechanism of the effect of microwave irradiation on the behavior of the chemical processes is still poorly understood, many studies have been published confirming the advantages of using of microwave activation to prepare various organic compounds [10-13].

At the moment, the use of the microwave activation in the vanillin (3) synthesis is described only for its production by curcumin oxidation [14], and the use of such an approach to the guaiacol (1) condensation with glyoxalic acid has not been found in the available literature.

\section{Experimental}

\subsection{Materials and methods}

Commercially available guaiacol (99\%, Aldrich Organics) and an aqueous solution of glyoxalic acid ( $50 \%$, Aldrich) were used as reagents. A solution of sodium hydroxide $(30 \%)$ was obtained by dissolving a portion of sodium hydroxide (chemically pure, Vecton).

The experiments using microwave irradiation were carried out using the «Speedwave four» microwave sample preparation system (Berghof Products + Instruments $\mathrm{GmbH}$ ) with a maximum power of $1450 \mathrm{~W}$ and a magnetron frequency of $2450 \mathrm{MHz}$ that allowed varying the temperature in the range of $50-230^{\circ} \mathrm{C}$.

To control the progress of the reactions, a reverse phase HPLC method was used on a Shimadzu LC-20 Prominence liquid chromatograph equipped with a PDA-20A UV detector.

\subsection{Synthesis using microwave irradiation}

A portion of $0.94 \mathrm{~g}(0.0075 \mathrm{~mol})$ of guaiacol was mixed with $11.5 \mathrm{ml}$ of water and $1.1 \mathrm{~g}$ of a $30 \%$ sodium hydroxide solution with vigorous stirring. $0.7 \mathrm{~g}(0.0047 \mathrm{~mol})$ of a $50 \%$ glyoxalic acid solution and $5.0 \mathrm{ml}$ of water were mixed separately. The resulting solutions were combined, placed in a fluoroplastic autoclave of the microwave system and kept for 10, 20 and 30 minutes at different temperatures and irradiation powers.

\subsection{Synthesis by the conventional procedure}

$9.3 \mathrm{~g}$ of guaiacol and $115.0 \mathrm{ml}$ of water were placed in a round bottom flask. $10.6 \mathrm{~g}$ of a $30 \%$ sodium hydroxide solution were added to the reaction mixture with a vigorous stirring. Then a mixture of $7.4 \mathrm{~g}$ of a $50 \%$ solution of glyoxalic acid and $50.0 \mathrm{~g}$ of water was added to the resulting sodium guaiacolate solution. The reaction mixture was kept at a temperature of $30^{\circ} \mathrm{C}$ from 5 to 25 hours.

\subsection{Synthesis by the conventional procedure}

To isolate the desired product (2), the reaction mixture was acidified up to a $\mathrm{pH}$ level of $4-5$ by the addition of hydrochloric acid and the excess of guaiacol was separated by extraction with benzene. The aqueous phase was acidified up to $\mathrm{pH}=1$ and the desired product was extracted with the ethyl acetate. The extract was evaporated to dryness and the bottom residue was recrystallized from a minimum amount of ethyl acetate. The product (2) was obtained with the $\mathrm{MP}=131-133{ }^{\circ} \mathrm{C}\left(132-133^{\circ} \mathrm{C}\right.$ in Ref. [3]). The IR spectrum: $v, \mathrm{~cm}^{-1}$ : $3336(\mathrm{OH}), 2971\left(\mathrm{CH}_{3}\right), 2932\left(\mathrm{CH}_{3}\right), 1744(\mathrm{C}=\mathrm{O}), 1713(\mathrm{C}=\mathrm{O}) .{ }^{1} \mathrm{H}$ NMR spectrum: $\delta$, ppm (DMSO-d 6$)$ : s.w. 12.47 , s. 8.96 , d. 6.96 , d. 6.78 , d. 6.72 , s.w. 5.68 , s. 4.89 , s. 3.75 .

\section{Results and discussion}

In the present work we studied the opportunity to synthesize vanillylmandelic acid (2) by the guaiacol (1) condensation with glyoxalic acid under the effect of the microwave irradiation as compared with the traditional synthesis method. With that, we conducted a series of experiments to determine the optimal synthesis conditions. The reaction mixture was subjected to the microwave irradiation with a power of $290,580,870$, and $1160 \mathrm{~W}$.

While conducting the experiments with varying the irradiation power without the additional heating (Table 1), no increase in the reaction rate is observed compared to the conventional synthesis procedure. The maximum yield achieved in 1 hour of the experiment for the product (2) (34\%) is comparable with the one obtained without the irradiation for the same synthesis time.

An increase in the heating of the reaction mixture contributed to an increase in the VMA yield. The best results were obtained when carrying out the reaction at a temperature of $70{ }^{\circ} \mathrm{C}$ (Table 1). The maximum VMA yield was achieved by irradiating the reaction mixture at a power of $870 \mathrm{~W}$ for 30 minutes. Further exposure of the reaction mixture is not feasible, since the yield of the desired product is gradually reduced that is probably due to the progressing side processes. 
VMA yield (2) dependence on the experimental conditions

\begin{tabular}{|c|c|c|c|c|c|c|}
\hline \multirow{3}{*}{$\begin{array}{l}\text { Seq. } \\
\text { No. }\end{array}$} & \multirow{3}{*}{ Irradiation rate, $\mathrm{W}$} & \multirow{3}{*}{ Temperature, ${ }^{\circ} \mathrm{C}$} & \multicolumn{4}{|c|}{ Time, min } \\
\hline & & & 10 & 20 & 30 & 60 \\
\hline & & & \multicolumn{4}{|c|}{ VMA yield, \% } \\
\hline 1 & 290 & No heating & 8 & 10 & 13 & - \\
\hline 2 & 580 & No heating & 9 & 11 & 15 & - \\
\hline 3 & 870 & No heating & 12 & 17 & 30 & 33 \\
\hline 4 & 1160 & No heating & 11 & 14 & 19 & 34 \\
\hline 5 & 290 & 70 & 62 & 63 & 66 & - \\
\hline 6 & 580 & 70 & 65 & 66 & 68 & - \\
\hline 7 & 870 & 70 & 65 & 68 & 71 & 67 \\
\hline 8 & 1160 & 70 & 66 & 67 & 66 & 65 \\
\hline
\end{tabular}

Under the conditions of the conventional synthesis procedure, the VMA (2) yield of about $70 \%$ can be achieved only after 10 hours (Fig. 2), that is, the synthesis time under the microwave activation is reduced by 20 times. However, the maximum yield of the desired product (2) is higher as compared with the irradiationless process. This is due to the acceleration of the side process of the formation of 4-hydroxy-5-methoxy-1,3benzene-diglyoxalic acid during the reaction at elevated temperatures. The results of the HPLC analysis of the reaction mixtures show that during the synthesis under the microwave irradiation, the content of this impurity in the reaction mixture is 2.5 times higher than in the synthesis without irradiation.

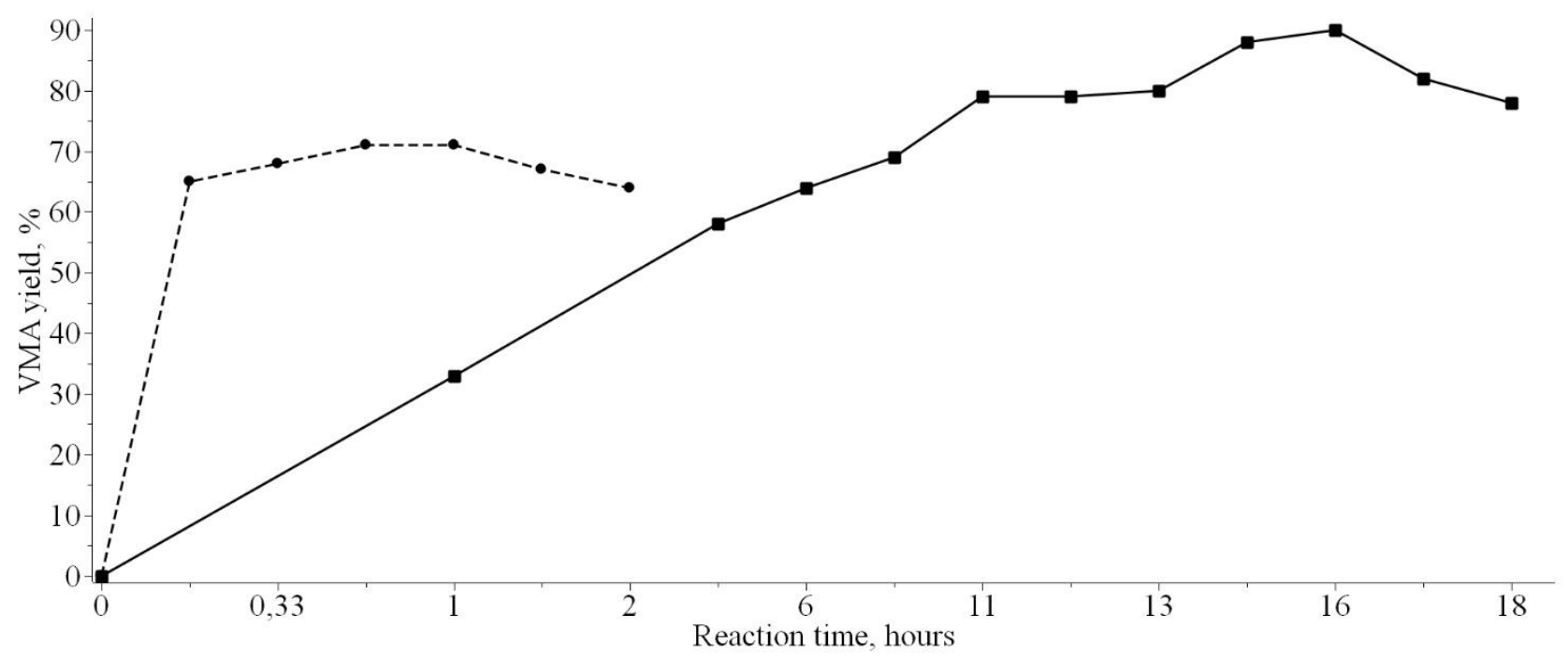

Figure 2. Dependence of VMA yield on the reaction time

\section{Conclusions}

Thus, for the first time, the synthesis of vanillylmandelic acid using the microwave irradiation was carried out and allowed us to reduce the synthesis duration by 20 times in comparison with the traditional methods. The best results were achieved when carrying out the reaction at $70{ }^{\circ} \mathrm{C}$ and the irradiation power of $870 \mathrm{~W}$.

\section{Acknowledgement}

This work was financially supported by the Ministry of Science and Higher Education of the Russian Federation in the framework of the Federal Target Program «Investigation and Developments on Priority Directions of Development of the Scientific Technological Complex of Russia for 2014-2020», Agreement No. 14.575.21.0170, unique identifier of project RFMEFI57517X0170. 


\title{
References
}

1 Mackie D.M. Guide book to Organic Synthesis / D.M. Mackie, D. Smith, R.A. Aitkin. — New York: Longman Scientific and Technical, 1990. - 103 p.

2 Niu D.-F. Impruved synthesis of 3-methoxy-4-hydroxymandelic acid by glyoxalic acid method / D.-F. Niu, H.-C. Li, X.-S. Zhang // Tetrahedron. — 2013. — Vol. 69. — P. 8174-8177. DOI: 10.1016/j.tet.2013.07.031

3 Fatiadi A.J. An Improved Procedure for Synthesis of DL-4-Hydroxy-3-methoxymandelic Acid (DL Vanillyll-mandelic Acid, VMA) /A.J. Fatiadi, R. Schaffer // Journal of Research of the National Bureau of Standards, Section A: Physics and Chemistry. 1974. - Vol. 78. - P. 411-412.

4 Kalikar R.G. Synthesis of Vanillin and 4-Hydroxybenzaldehyde by a Reaction Scheme Involving Condensation of Phenols with Glyoxylic Acid / R.G. Kalikar, R.S. Deshpande, S.B. Chandalia // Journal of Chemical Technology and Biotechnology. - 1986. — Vol. 36. - P. 38-46. DOI: 10.1002/jctb.280360107

5 Selikhova N.Yu. Optimization of the conditions of guaiacol and glyoxylic acid condensation to vanillylmandelic acid as an intermediate product in vanillin synthesis / N.Yu. Selikhova, D.A. Kurgachev, V.S. Sidelnikov, D.V. Novikov, V.V. Botvin, O.K. Poleshchuk // Journal of Physics: Conference Series. - 2019. - Vol. 1145. - P. 012047. DOI: 10.1088/1742$6596 / 1145 / 1 / 012047$

6 Patent No. 2016/0297735 US. Process for preparing mandelic aromatic compounds and aromatic aldehyde compounds. Issued 2016 / Garel L., Sarrazin F., Back O., Olivon K., Purcheault M.

7 Varala R Synthesis of mandelic acid derived phthalimides as a new class of anti-inflammatory and antimicrobial agents / R. Varala, V. Kotrac, M.M. Alama, N.R. Kumarb, S. Ganapatyc, S.R. Adapa // Indian Journal of Chemistry. — 2008. — Vol. 47B. P. 1243-1248. DOI: $10.1002 /$ chin.200849115

8 Patent No. 101012161 CN. Method of synthesizing 3-methoxy-4-dydroxymandelic acid or 3-ethoxy-4-dydroxymandelic acid by acetaldehyde acid method. Issued 2007 / Li Y., Wei G., Liu N., Hou Sh., Liu Ch.

9 Хрусталев Д. Синтез азотсодержащих веществ в условиях микроволновой активации: история, теория, эксперимент / Д. Хрусталев, А. Газалиев. — Берлин: LAP LAMBERT Academic Publishing, 2011. — 356 c.

10 De la Hoz A. Microwaves in organic synthesis. Thermal and non-thermal microwave effects / A. De la Hoz, A. Díaz-Ortiz, A. Moreno // Chem. Soc. Rev. — 2005. - Vol. 34(2). — P. 164-178. DOI: 10.1039/b411438h

11 Diaz-Ortiz A. A Critical Overview on the Effect of Microwave Irradiation in Organic Synthesis / A. Diaz-Ortiz, P. Prieto, A. de la Hoz // The Chemical Record. — 2018. — Vol. 18. — P. 1-14. DOI: 10.1002/tcr.201800059

12 Шавшукова С. Использование микроволнового излучения в органическом синтезе: основные реакции и методы воздействия / С. Шавшукова, С. Злотский. — Берлин: Lambert Academic Publishing, 2011. — 85 c.

13 Мызников Л.В. Микроволновая активация в химии тетразолов / Л.В. Мызников, С.В. Ворона, Т.В. Артамонова, Ю.Э. Зевацкий // Химия гетероциклических соединений. — 2016. — Т. 52(11). — С. 887-893.

14 Bandyopadhyay D. Bismuthnitrate-induced microwave assisted expeditious synthesis of vanillin from curcumin / D. Bandyopadhyay, B.K. Banik // Org. Med. Chem. Lett. — 2012. — Vol. 2. — P. 15. DOI: 10.1186/2191-2858-2-15

\section{Н.Ю. Селихова, В.С. Мальков, А.А. Бакибаев \\ Микротолқынды сәулелену кезіндегі гваякол мен глиоксал қышқылының реакциясы}

\begin{abstract}
Мақалада ванилин синтезінің жартылай өнімі болып табылатын 4 гидрокси-3-метоксиминдаль қышқылын препаративтік әдіспен алу мақсатында конвекциялық қыздыру әдісіне балама ретінде микротолқынды сәулелену әдісін пайдалану арқылы натрий гидроксиді қатысында сулы ерітіндідегі гваякол мен глиоксал қышқылының конденсация реакциясы қарастырылған. Тәжірибелер сәулелену қуатын 0-ден 1450 Вт-қа дейінгі интервалда тәжірибе жүргізуге болатын «Speedwavefour» микротолқынды жүйесі көмегімен жүргізілген. Конденсация реакциясы 290, 580, 870 және 1160 Вт сәулелену куаты жағдайында жүрді. Реакция жағдайларын өзгерте отырып, тәжірибелерді жүргізу барысында конденсация реакциясының негізгі өнімінің түзілуіне уақыт, температура және микротолқынды қуаттың әсері анықталған. Өнімнің ең жоғары шығымын алуға мүмкіндік беретін эксперимент шарттары анықталған: реакция қоспасының температурасы $70{ }^{\circ} \mathrm{C}$ және сәулелендіру куаты 870 Вт. Синтездеу уақыты 30 мин құрады. Микротолқынды активтендіру және дәстүрлі әдісті қолданып реакцияны жүргізу жағдайындағы 4-гидрокси-3-метоксиметин қышқылы синтезінің нәтижелеріне салыстыру жасалған. Микротолқынды сәулеленуді қолдану синтездеу уақытын едәуір қысқартады (20 есе), алайда бұл әдіс нәтижесінде алынған өнімнің шығымы дәстүрлі әдіске қарағанда төмен болып шықты. Синтезделіп алынған 4-гидрокси-3-метоксиминдаль қышқылының туындыларының құрылысы ИҚ-, ${ }^{1} \mathrm{H}$ және ${ }^{13} \mathrm{C}$ ЯМРспектроскопия әдістерінің нәтижелерін талдау арқылы дәлелденген.
\end{abstract}

Кілт сөздер: ванилминдаль қышқылы, гваякол, глиоксал қышқылы, конденсация, микротолқынды сәулелену. 


\title{
Н.Ю. Селихова, В.С. Мальков, А.А. Бакибаев \\ Реакция гваякола и глиоксалевой кислоты в условиях микроволнового облучения
}

\begin{abstract}
В статье рассмотрена возможность применения микроволнового облучения в качестве альтернативы конвекционному способу нагрева при проведении реакции конденсации гваякола и глиоксалевой кислоты в водном растворе в присутствии гидроксида натрия с целью препаративного получения 4 гидрокси-3-метоксиминдальной кислоты, являющейся полупродуктом синтеза ванилина. Эксперименты под воздействием микроволнового облучения были проведены с использованием микроволновой системы «Speedwavefour», позволяющей варьировать мощность облучения в интервале от 0 до 1450 Вт. Реакцию конденсации проводили при мощности облучения 290, 580, 870 и 1160 Вт. В ходе проведенных экспериментов путем варьирования условий реакций установлено влияние времени, температуры и мощности микроволнового облучения на выход целевого продукта реакции конденсации. Определены условия проведения эксперимента, позволяющие получить наибольший выход продукта данным методом, а именно: температура реакционной смеси $70{ }^{\circ} \mathrm{C}$ и мощность облучения 870 Вт. При этом время синтеза составило 30 мин. Проведено сравнение результатов синтеза 4 гидрокси-3-метоксиминдальной кислоты в условиях микроволновой активации и традиционным методом. Установлено, что использование микроволнового облучения позволяет значительно (до 20 раз) сократить время синтеза, однако максимальный достигнутый данным методом выход продукта оказался ниже по сравнению с традиционным методом. Строение синтезированных образцов 4-гидрокси-3-метоксиминдальной кислоты подтверждено результатами анализа методами ИК-, ${ }^{1} \mathrm{H}$ и ${ }^{13} \mathrm{C}$ ЯМР-спектроскопии.
\end{abstract}

Ключевые слова: ванилилминдальная кислота, гваякол, глиоксалевая кислота, конденсация, микроволновое облучение.

\section{References}

1 Mackie, D.M., Smith D., \& Aitkin R.A. (1990). Guide book to Organic Synthesis. New York: Longman Scientific and Technical.

2 Niu, D.-F., Li, H.-C., \& Zhang, X.-S. (2013). Impruved synthesis of 3-methoxy-4-hydroxymandelic acid by glyoxalic acid method. Tetrahedron, 69, 8174-8177. DOI: 10.1016/j.tet.2013.07.031

3 Fatiadi, A.J., \& Schaffer, R. (1974). An Improved Procedure for Synthesis of DL-4-Hydroxy-3-methoxymandelic Acid (D,L-Vanillyll-mandelic Acid, VMA). Journal of Research of the National Bureau of Standards, Section A: Physics and Chemistry, $78,411-412$.

4 Kalikar, R.G., Deshpande, R.S., \& Chandalia, S.B. (1986). Synthesis of Vanillin and 4-Hydroxybenzaldehydeby a Reaction Scheme Involving Condensation of Phenols with Glyoxylic Acid. Journal of Chemical Technology and Biotechnology, 36, 38-46. DOI: $10.1002 /$ jctb.280360107

5 Selikhova, N.Yu., Kurgachev, D.A., Sidelnikov, V.S., Novikov, D.V., Botvin, V.V., \& Poleshchuk, O. Kh. (2019). Optimization of the conditions of guaiacol and glyoxylic acid condensation to vanillylmandelic acid as an intermediate product in vanillin synthesis. Journal of Physics: Conference Series, 1145, 012047. DOI: 10.1088/1742-6596/1145/1/012047

6 Garel, L., Sarrazin, F., Back, O., Olivon, K., \& Purcheault, M. (2016). Process for preparing mandelic aromatic compounds and aromatic aldehyde compounds. U.S. Patent No. 2016/0297735. Washington, DC: U.S. Patent and Trademark Office.

7 Varala, R., Kotrac, V., Alam, M.M., Kumar, N.M., Ganapaty, S., \& Adapa, S.R. (2008). Synthesis of mandelic acid derived phthalimides as a new class of anti-inflammatory and antimicrobial agents. Indian Journal of Chemistry, 47B, 1243-1248. DOI: 10.1002/chin.200849115

8 Li, Y., Wei, G., Liu, N., Hou, Sh., Liu, Ch. (2007). Method of synthesizing 3-methoxy-4-dydroxymandelic acid or 3-ethoxy4-dydroxymandelic acid by acetaldehyde acid method. China Patent No. 101012161.

9 Khrustalyov, D., \& Gazaliev, A. (2011). Sintez azotsoderzhashchikh veshchestv v usloviiakh mikrovolnovoi aktivatsii: istoriia, teoriia, eksperiment [Synthesis of the nitrogen-containing substances under microwave irradiation conditions: history, theory, experiment]. Berlin: LAP LAMBERT Academic Publishing [in Russian].

10 De la Hoz, A., Díaz-Ortiz, A., \& Moreno, A. (2005). Microwaves in organic synthesis. Thermal and non-thermal microwave effects. Chemical Society Reviews, 34(2), 164-178. DOI: 10.1039/b411438h

11 Díaz-Ortiz, A., Prieto, P., \& de la Hoz, A. (2018). A Critical Overview on the Effect of Microwave Irradiation in Organic Synthesis. The Chemical Record, 18, 1-14. DOI: 10.1002/tcr.201800059

12 Shavshukova, S., \& Zlotskiy, S. (2011). Ispolzovanie mikrovolnovoho izlucheniia v orhanicheskom sinteze: osnovnye reaktsii $i$ metody vozdeistviia [Usage of microwave irradiation in organic synthesis: Main reactions and stimulation technique]. Berlin: Lambert Academic Publishing [in Russian].

13 Myznikov, L.V., Vorona S.V., Artamonova, T.V., \& Zevatskiy, Yu.E. (2016). Mikrovolnovaia aktivatsiia v khimii tetrazolov [Microwave activation in tetrazole chemistry]. Khimiia heterotsiklicheskikh soedinenii. - Chemistry of heterocyclic compounds, 52(11), 887-893 [in Russian].

14 Bandyopadhyay, D., \& Banik, B.K. (2012). Bismuth nitrate-induced microwave assisted expeditious synthesis of vanillin from curcumin. Organic and Medicinal Chemistry Letters, 2:15. DOI: 10.1186/2191-2858-2-15 